\title{
Digitális identitás - nyelvi identitás - digitális kommunikációs környezet
}

A tanulmányban a szerző bemutatja, hogy a digitális térben zajló kommunikáció, az IT nyelvi környezete, nyelvhasználata miként hat az identitás különböző rétegeire és a nyelvi identitásra. Az identitásunk része a digitális, internetes környezetben alkalmazott nyelvhasználat is. Ennek néhány meghatározó eleme: a többnyelvüség, az interaktivitás, a multimedialitás, a technológiai környezet, az önreklámozás és önkifejezés, a közösségi média és az ott előforduló visszaélések, az online videojátékok nyelvi környezete.

Kulcsszavak: identitás, információs társadalom, nyelvhasználat, többnyelvüség, nyelvstratégia

\section{Szerzői információ}

Bódi Zoltán, Magyarságkutató Intézet, Nyelvtervezési Kutatóközpont https://mki.gov.hu/hu/kutatokozpontok/nyelvtervezesi-kutatokozpont

Így hivatkozzon erre a cikkre:

Bódi Zoltán. „Digitális identitás - nyelvi identitás - digitális kommunikációs környezet”. Információs Társadalom XX, 3. szám (2020): 7-26. 


\section{Digital Identity - Language Identity - Digital Communication Environment}

The digital or virtual identity is part of identity (personal, group, national et. c). The author demonstrates how the communication in the cyberspace, the IT language effects on the different layers of the identity and the language identity. The language usage in the cyberspace is part of the identity. Some important elements of this: multilingualism, interactivity, multimediality, information technology, self-representation, social media and the abuses in the social media, language usage of the videogames.

Keywords: indentity, information society, language usage, multilingualism, language strategy 


\section{Célmeghatározás}

Az identitás rétegei közül ezúttal a digitális identitás fogalmát tanulmányozom. A digitális identitást általában az interneten regisztrált vagy ott használatos személyes adatokkal, illetve azok védelmével azonosítják. Célom, hogy felmutassam: a digitális identitásnak része az internetes környezet nyelvhasználata is, és ez természetesen kapcsolatban van a nyelvi identitásunkkal is.

Az internetes, digitális környezet és a digitális identitás kapcsolatát az alábbi kulcsfogalmak határozzák meg: többnyelvűség, írott beszélt nyelv és szimbolikus írásbeliség, interaktivitás, technológiai környezet, önreklámozás és önkifejezés, közösségi hálózatok és az ott előforduló visszaélések, információbiztonság, online videojátékok, internetfüggőség.

\section{A digitális identitás fogalmáról}

Az identitást számos kutató, számos nézőpontból tárgyalta és tárgyalja, sőt a közéletet és a kultúrát is folyamatosan foglalkoztatja. Ezúttal azt kívánom a gondolatmenetem középpontjába helyezni, hogy az identitás állandó elemeire folyamatosan újabb rétegek rakódnak: megjelent a digitális identitás, mely egyre meghatározóbb szerepet tölt be az ettől egyre összetettebbé váló identitásunkban. Emellett a hagyományosan állandónak számító identitásunk a digitális kommunikációs környezetnek köszönhetően képes módosulni, változni.

„Az identitás sajátos szerveződésű kognitív struktúra, amely az ember társadalmiasulásának, környezetébe való belenövekedésének, szakszóval szocializációjának folyamatában alakul ki. A nyelv az ember kognitív felszereltségének része, ennek következtében egész mentális tevékenységünk, így az identitás kialakulása is a nyelvvel, a nyelv közvetítésével zajlik” (Kiss 2017, 806). Nyilvánvaló tehát, hogy a digitális identitás áttekintésekor figyelmet kell fordítani a nyelvre, a nyelvhasználatra, az internet nyelvi és kommunikációs környezetére.

Susan Greenfield agykutatótól igazán hitelesen hangzik az a megállapítás, hogy az agyunk müködésében az identitás, másképp fogalmazva az önazonosság, a „mi magunk” fogalma állandó, ez alapján éljük le az életünket, és ez alapján lépünk kölcsönhatásba másokkal.

Azonban bármennyire is állandó az identitás, a mindenkori viselkedésünk - így a nyelvi viselkedésünk is - függ a környezetünktől, az elvárásoktól és a helyzettől, emiatt az agyunkban folyamatos változások mennek végbe. Greenfield szerint az identitásunk a XXI. században jobban ki van téve a változásoknak, mint eddig bármikor (Greenfield 2009, 117-119.). Állandó vagy változó-e tehát az identitás? Mivel több rétege van, és ezek a rétegek folyamatosan változhatnak, új rétegek jelenhetnek meg, ezért az identitásunknak is szükségszerűen vannak változó elemei. Ugyanakkor a személyiségünk alapvonásai, az anyanyelvünk és az ahhoz kapcsolódó kulturális háttér meghatározó 
szerepe nem változik. A greenfieldi gondolatsorban a XXI. század változást okozó elemei közé tartozik a digitális kommunikációs környezet egyre erőteljesebb, egyre általánosabb szerepe.

Megele, Buzzi és Longfield szerint is újabb dimenziókat tettünk hozzá az identitáshoz a technológiának köszönhetően, így az identitás még szerteágazóbbá és még összetettebbé vált (Megele, Buzzi és Longfield 2018).

Értelmezésem szerint az identitás az önazonosságunk alapvető része, olyan összetett, soktényezős fogalom, amelyben a nyelv meghatározó szerepet játszik. A mai világban viszont az identitás - benne a nyelvi identitás - állandósága is folyamatos változásoknak van kitéve. Különösen érvényes ez a valós és a virtuális térben élő nemzeti, nyelvi kisebbségekre.

Ha az identitás több rétegéből a digitális identitásra koncentrálunk, akkor kiindulópontnak választhatjuk Fehér Katalin meghatározását. „A digitális identitás egy online elérhető adatkészlet, amely az Én kivetülése és leképeződése a digitalizált színtereken” (Fehér 2014,139). Ez a meghatározás azon túl, hogy elválasztja a digitális identitást az identitás többi rétegétől, erősíti azt az elképzelést, hogy a digitális identitás technológiai oldalról közelíthető meg.

Fehér Katalin összefoglalja, hogy a digitalizálódó énre milyen terminusok alakultak ki (Fehér 2014, 140): online identitás (Kim et al., 2011), e-dentitás (Vie, 2011), Én 2.0 (Schawbel, 2009), digitális denotátum [digitális adatok, amelyek azonosítják a felhasználót] (Sarma és Girão, 2009), személyes és professzionális azonosíthatóságot biztosító digitális adatok (Deloitte Tech Trends, 2013). Susan Greenfield pedig az online térben megjelenő avatárokkal szimbolizálja ezt, és leginkább az általa Senki-identitásnak nevezett típushoz sorolja (Greenfield 2009, 195). Én a digitális identitás terminust választom.

A digitális identitásunkat valakikhez, valamikhez képest határozzuk meg, tehát az összehasonlító jelleg, a hasonlóak közül való kitűnés, az egyéni jellemzők kiemelése a meghatározó. Fehér a személyes digitális identitás esetében a közösségi hálózatokat (tehát a web 2.0 szolgáltatások közösségeit), a vállalati digitális identitás esetében a mai, divatos szakkifejezés szerint a stakeholdereket, magyarul az érintettek (például befektetők, ügyfelek, beszállítók, alkalmazottak, média stb.) körét emeli ki viszonyítási pontként, meghatározó tényezőként (Fehér 2014, 125).

Egyetértek azzal, hogy a digitális identitás kérdésköre a közösségi média megjelenése után vált relevánssá a tudományban és a közbeszédben egyaránt. Ekkor szembesültünk azzal, hogy a felhasználó önmaga irányíthatja és tudatosan építheti a saját identitását az online, digitális térben: lásd például a Facebook-profiloldalakat, a közzétett fényképeket, a bemutatkozó szövegeket, az ismerősök megválogatását (vagy éppen válogatás nélküli befogadását), a közzétett posztokat, kommenteket, tetszésnyilvánításokat, a közösségi hálózatokon használt nyelvet. A World Wide Web, a közösségi média korában a digitális nyilvánosság előtt megjelenő identitásunkat mi magunk formáljuk, mi magunk válunk márkává, még akkor is, ha ezt nem akarjuk, vagy esetleg nem is tudunk róla. 
Fehér Katalin szerint a puszta webes vagy közösségi médiás jelenlétünkkel, tevékenységünkkel digitális adatkészletet hozunk létre, amely kapcsolódik hozzánk, és azonosíthatók vagyunk általa (Fehér 2014, 139). A digitális identitásunk a virtuális térben megjelenő egyéniségünk. A virtuális tér virtuális szabályok szerint müködik, és ezek a virtuális szabályok esetleges viszonyban vannak a térbeli valóságra vonatkozó szabályokkal. Végletesen nem szakíthatunk a személyes identitásunkkal a virtuális térben, de bizonyos pontjait, tényezőit kisebb-nagyobb hatókörben átalakíthatjuk és tudatosan átformálhatjuk.

A digitális identitás voltaképpen egy online énreprezentáció digitális adatok formájában, és ez szükségszerüen le van egyszerüsítve, és sosem felelhet meg tökéletesen a valós személyes identitás minden elemének. Tehát a valós életben érvényesülő szabályszerűségek, személyiségjellemzők virtuális térbe helyezésével adathalmazzá és viszonylagossá válnak.

Greenfield az identitás meghatározását három forgatókönyv szerint végzi el: a Valaki-, a Senki- és az Akárki-forgatókönyv szerint. Most röviden áttekintem ezeket, és a greenfieldi kategóriák továbbgondolásával építem fel a magam digitálisidentitás-fogalmát, amelyben hangsúlyt helyezek a nyelvi, nyelvhasználati szempontokra.

Valaki-forgatókönyv lényege a valakinek lenni érzése, az elménk tartós elképzelése önmagáról, voltaképpen az önmagunkról alkotott definíció (Greenfield 2009, 120-122). A külső körülmények, a környezet meghatározza a Valaki-forgatókönyv szerinti identitást.

Greenfield szerint a biotechnológia és az információtechnológia veszélybe sodorja a belső magánszférát, mivel minden nyilvános lesz, pedig az énünk esszenciája a privát szféra, a magánélet, az egyéni érzések és a személyes gondolatok tere. Ha mindennek sérül a magánjellege, akkor az önazonosságunk, azaz az identitásunk is sérül. A modern információtechnológia miatt megszűnik az a lehetőségünk, hogy névtelenek maradhassunk. A különböző adatbázisok összekapcsolása (egészségügy, pénzügy, lakcím, kereskedelmi és fogyasztói szokások) személyes profilokat hoz létre önmagunkról. Ezek az elektronikus lábnyomok, amelyek olyan mélyek, hogy a kibertérben a tökéletes identitáslopás is megvalósulhat (Greenfield 2009, 129-130).

Érdemes itt figyelembe venni Kiss Jenő megjegyzését: „Az identitás jelentése: önazonosság(tudat), hovatartozás(tudat). Mint ilyen, sajátos emberi attribútum, tehát a Homo sapiens sapiens jellemző lényegi jegye, amely nélkül az egyén társadalmilag versenyképtelen volna. Elvesztése személyes tragédia, patologikus eset, a környezetet is súlyosan megterhelő állapot” (Kiss 2017, 806). Mindez a digitális térben már egészen mást jelent, hiszen a digitális identitás elvesztése nemcsak patológiás állapotként fordulhat elő, hanem közönséges adatlopás következtében is, ám a hatása szélsőséges esetben akár patológiás állapotot is előidézhet. A szilárdnak és változtathatatlannak megismert identitás fogalma tehát a virtuális térben könnyen, gyorsan és akár végletesen is átalakulhat. Ez viszont a személyes identitásunkat csak korlátozottan vagy 
egyáltalán nem befolyásolja: a digitális identitásunk tehát a személyes identitásunkkal szükségszerü kapcsolatban van, de nem egyezik meg vele.

A belső magánvilágunk létfontosságú abban, hogy tudatában legyünk annak, hogy az identitásunk különbözik a többi személyétől. Ám az is igaz, hogy a valakivé válás végletes hajszolása a szükségletek (biztonságérzet, csoporthoz tartozás, kompetencia és önállóság) elhanyagolásával jár (Greenfield 2009,149). Óhatatlanul belső konfliktust okoz mindez, amit magyaráz Maslow jól ismert modellje is: az önmegvalósítás a szükségletek csúcsán áll, és optimális esetben az alatta lévő szükségletek kielégítése után lehet elérni (Maslow 2016 [1968]).

Mindebből levezethető, hogy a virtuális térben az egyéni identitás előtérbe helyeződésével a közösségi normák kevésbé fontosak, így akár az anyanyelv normatív, sztenderd változata is. Inkább az egyéni nyelvváltozatok elismerése és használata, sőt akár az idegen nyelvek előtérbe helyeződése figyelhető meg. Ezt a folyamatot a digitális kultúra, az internet, a közösségi hálózatok felerősítik, hisz - a későbbiekben is utalok rá, hogy - különösen a közösségi hálózatokon jellemző a szereplők egyéni jellemzőinek előtérbe helyezése, pozitív tulajdonságaiknak a kiemelése.

Greenfield továbbmegy a XXI. századi identitástípusok elemzésében, meghatározza a Senki-forgatókönyvnek nevezett típust is. Eszerint a kibertérben leegyszerűsödik a mentalitás, hisz a valós életben sokkal összetettebb minden. Az online környezetben megnyilvánuló egyén jellemzően szélsőséges, végletes, kétpólusú ítéleteket alkot, amelyekben a pillanatnyi élmény túlsúlya kifejezetten meghatározó. Az agykutató Greenfield szerint a kibertérben teljesen új identitást lehet szerezni új külsővel, új életkorral, új külső jegyekkel, és virtuális pénzen még virtuális ruhákat is vehetünk magunknak (Greenfield 2009, 195-197). Itt köszön vissza a korábbi megállapításunk: ez a „teljesen új” digitális identitás viszont csak átmenetileg, a virtuális tér bizonyos, jól meghatározható tereiben érvényesül, és a valós, személyes identitással csak esetleges kapcsolatban lehet.

Míg a Valaki-forgatókönyv magánéleti, és nem teljesíthető be, addig a Senki-forgatókönyv nem magánéleti, és szintén nem teljesíthető be.

A greenfieldi Senki-forgatókönyv alternatívái: a „hamis identitás” és a „kollektív identitás”. A hamis identitás az interneten az avatár, ami a szanszkrit avatára 'inkarnáció', 'megtestesülés' származéka; az avatár a kibertérbeli másodlétezés (Greenfield 2009, 195-197).

A digitális identitásnak ez a rétege tudatosan alkotott személyiség, amelylyel azonosulni lehet. És a digitális identitásban éppen ez a tudatos alakíthatóság a legnagyobb újdonság. A közösségi hálózatok szabályszerűségei miatt az avatár idealizált személyiségjegyekkel rendelkezik, és egyre inkább hasonlít a valós személyiséghez: már az avatárok is kezdenek testbeszédet, metakommunikatív eszközöket használni. A XXI. század második évtizedének vége felé megjelennek azok a mesterségesintelligencia-alapú beszédszintetizátorok és avatárok, amelyeknek ugyan nincs még kiforrott metakommunikációjuk, a fontetikai eszközökkel, a prozódiával csak minimálisan élnek, de határozottan 
fejlődőképesek, ilyenek például az okostelefon rendszerekben vagy a számítógépes operációs rendszerekben megtalálható digitális asszisztensek (például az Apple iOS okostelefonos műveleti rendszerének digitális asszisztense: Siri, vagy a Windowsban elérhető Cortana, de említhetjük Vandát is, a Magyar Telekom ügyfélszolgálatának virtuális asszisztensét). Ezek és az ezekhez hasonló avatárok tehát kommunikációs téren is fejlődőképesek. Izgalmas perspektívát nyújt, hogy a mesterséges intelligenciának köszönhetően már ma is léteznek olyan digitális identitások, amelyeknek nincs meg a valós térben lévő személyes változatuk. Újabb érv amellett, hogy a virtuális tér virtuális szabályszerűségeket követve müködik, és a térbeli valósággal való kapcsolat csak esetleges, és nem törvényszerü.

Az avatárok kommunikációja az offline kommunikációhoz képest egyszerübb, a valós térben zajló, spontán beszélgetés sokkal összetettebb. Ez a kommunikációs környezet pedig nyomot hagy a felhasználók kommunikációs szokásaiban, nyelvhasználatában. Greenfield észrevétele jól megvilágítja a helyzetet: ugyanolyan nehéz az avatárok világában a valós térben zajló spontán kommunikáció értelmezése, mint nekünk az őseink vadászó életmódja: ma már senki sem vadászik élelemszerzés céljából, a húst a szupermarketben vesszük lefóliázva (Greenfield 2009, 198). Az összetettebb, szofisztikáltabb folyamatok mindig nehezebben értelmezhetők, és igaz ez a nyelvhasználatra is: a digitális környezet a technológiai adottságaival a leegyszerüsített, szűkített kommunikációs csatornákon zajló kommunikációs folyamatokat és nyelvhasználatot részesíti előnyben. Az avatár identitással tartósan élők személyes identitására az avatár identitás biztosan hatást gyakorol, de még nem tárták fel a kutatások ennek a kapcsolatnak a mélységeit. Annyi bizonyosan állítható, hogy a leegyszerűsített kommunikáció, a nyelvi szocializáció során mintákat építhet ki. Különösen a gyermekek esetében érdemes kezelni ezt a folyamatot, mert ők pont abban a korszakban vannak, amikor a változatos, kifinomult kommunikációs folyamatok, a nyelvhasználat változatosságának elsajátítása révén alakítják ki nyelvi és kommunikatív kompetenciájukat. Ha ekkor kizárólag vagy túlsúlyban egyoldalú, leegyszerüsített nyelvi formákkal találkoznak, akkor várható, hogy a nyelvi, kommunikációs készségük sem épül ki megfelelően. Erre érdemes nyelvstratégiát alkotni, a játék- és avatárkultúra kommunikatív jellemzőit az iskolai színtéren is elemezni kell.

A greenfieldi Senki-forgatókönyv másik alternatívája: a kollektív identitás: az egységesen gondolkodó közösség, például a flashmobok, a Wikipédia mögött álló közösségek (Greenfield 2009, 199). A kollektív identitás embere egy csomópont a gondolatok hálózatában, olyan létezési mód egyik eleme, amelynek nem fontos szempontja, feladata az egyéni kifejezés, annál lényegesebb viszont a közös, kollektív gondolati és identitáshálózatba való belesimulás. Tehát a virtuális világ, a kibertér virtuális szabályai, az odaillő egyszerűbb, biztonságosabb, egyértelműbb kommunikáció és nyelv más szabályok szerint müködik, mint a valós térben, valós szereplők között zajló kommunikáció, és ez hat a nyelvhasználatra is. 
Az Akárki-forgatókönyv szerit egy csoport tagjai vagyunk, és a csoport tagjai közül akárkik lehetnénk. Az egyén ekkor önmagát a másokéval közös tulajdonságok szerint határozza meg. Eszerint a legegyszerübben úgy tudjuk meghatározni, hogy kik vagyunk, ha besoroljuk magunkat néhány csoportba, amelynek születésünktől fogva vagy szabad akaratunkból váltunk tagjává (Greenfield 2009, 201). Ezeknek a csoportoknak az egyik típusa a nemzet, tehát ne feledjük, hogy nemcsak személyes, magánéleti identitásunk van, hanem csoportos, közéleti, nemzeti is. A virtuális közösségekhez, csoportokhoz való kapcsolódás is egyre erőteljesebben válik részévé a digitális identitásunknak, és a személyes identitásunknak is.

A szilárd alapokon nyugvó kollektív identitástudathoz a közös tulajdonságokon túl közös hitrendszer is kell: az értékek és a személet közössége. A magyar nemzeti identitás központi, szimbolikus eleme a magyar nyelv, és ez a magyar nemzet sajátos történelmi, geopolitikai helyzetéből adódik: elég csak a Kárpát-medencei elhelyezkedésünkre, kisebbségi és szórvány csoportjainkra és ezeknek a csoportoknak a magyar nyelvhasználati lehetőségeire gondolni. Greenfield szerint az Akárkik agyában a külső kulturális tényezők hatására kiépülnek a szimbólumok, a jelképek (Greenfield 2009, 204). Tehát ez alapján könnyen érthető, hogy az Akárki-identitás egyik megvalósulása a nemzeti identitás, és a nemzeti identitás egyik meghatározója a nemzeti nyelv mint a csoportot alapvetően meghatározó tartozó jelkép- és szimbólumrendszer. A virtuális tér adottságait ismerve beláthatjuk, hogy ez a környezet erőteljesen multilingvális, többnyelvű, főként a kisebb beszélőközösséggel és nyelvi vitalitással rendelkező nyelvek tudnak kevésbé érvényesülni az interneten. A nemzeti nyelv a digitális identitásban tehát fontos, de korlátozott szerepet játszik.

A közösségi médiában a nárcisztikus vonások felülreprezentáltsága figyelhető meg (Tari 2015, 25). Ez az állítás erősíti azt az észrevételt, hogy az az identitás, amit a közösségi médiában felépítünk, jellemzően a digitális környezetünkhöz, az ismerőseink digitális identitásához viszonyítva építjük ki. Tehát nem feltétlenül objektív és őszinte, hanem inkább viszonylagos, nárcisztikus, vagyis az előnyös vonásainkat helyezi előtérbe. És mindez tudatos folyamat eredménye. „Fennáll a veszélye annak, hogy az ember azonossága már nem belső interiorizáció kérdése lesz, hanem a többiekkel való kapcsolatok által meghatározott” (Tari 2015, 108). Greenfield szerint a másokhoz viszonyított identitás a Valaki-identitás típusának jellemzője, amelyben az egyéni értékek közösségi élmény nélküli érvényesítése a legfontosabb (Greenfield 2009, 122). Azzal viszont kevésbé, vagy akár egyáltalán nem, szembesülünk, hogy a digitális identitásunk digitális adatokban is megnyilvánul, és ezeknek a tudatos kontrollálása egyre nagyobb feladatot ró az egyénre és a fejlesztőkre, a szolgáltatókra egyaránt.

A digitális identitás részben a felhasználó akaratán kívül, a puszta internetes, digitális, online tér müködésének következtében alakul ki. Úgy jön létre, hogy a felhasználó internetes, digitális vagy online rendszerekben való tevékenysége során adatokat hagy a rendszerekben, amelyeket azok megőriznek 
vagy másolatot készítenek róluk. Ebből áll össze a digitális lábnyom. A digitális lábnyom alapján áll össze a digitális identitás (Fehér 2014, 139). Ez tehát egy technikai-technológiai típusú definíció, ami leegyszerüsíti és a lehető legjobban összefoglalja a digitális identitás összetevőit: végsősoron igaz, hogy a digitális rendszerekben minden adatszerűvé válik, akár a személyiségünk összetevői is.

A kibertérben a felhasználókról termelt személyes adatok nemcsak Európában, hanem az Egyesült Államokban is egyre nagyobb aggodalmat keltenek az információs társadalom polgáraiban. Holt és Malčić felmérése eszerint az amerikaiak 90 százaléka szerint a felhasználók elvesztették a kontrollt a vállalatok által róluk összegyüjtött és digitalizált személyes adatok fölött, és 80 százalékuk szerint hozzá kell szokni ahhoz a gyakorlathoz, hogy az Egyesült Államok kormánya figyeli a telefonhívásokat és a felhasználók internetes tevékenységét (Holt, Jennifer és Malčić 2015, 155). Mindez azonban az offline térben reprezentálódó identitásunkra csak esetlegesen gyakorol hatást.

Egy identitás van, amely offline és online térben is reprezentálódik, és az online térben leginkább a közösségi médiában folytatott diskurzusainkban mutatkozik meg. A teljes online tevékenységünk során (tudatosan és nem tudatosan) kialakuló digitális adatkészlet (digitális lábnyom) alapján alakul ki a digitális identitás (Fehér 2014, 139). Az identitásunk online térben való reprezentálódása szempontjából fontos a nyelvhasználat, a nyelvi környezet.

\section{A nemzedékek viszonya a digitális identitáshoz}

Ifj. Csákvári József tanulmányában elsősorban a gyermekek identitása és a digitális, hálózati kultúra összefüggéseire koncentrál, de egy átfogóbb áttekintéshez is jó alapot ad: „Kiindulópontunk az, hogy az internet és a különböző digitális eszközök elterjedésével párhuzamosan kifejlődött egy globális - egyben kulturális identitások tekintetében differenciálódó, azaz »törzsi« jellegű - digitális hálózati gyerek-kultúra, amelynek értékrendje és normái radikálisan különböznek és elkülönülnek a fiatalok életének más területeitől” (ifj. Csákvári 2016). Ez értelmezhető úgy, hogy a digitális térben (a számítógépes eszközök, a világháló környezete, az alkalmazások, a video- és digitális játékok stb.) a kulturális identitásnak újabb rétegei alakulnak ki, amelyek illeszkednek az adott kontextus normáihoz, elvárásaihoz. Csak az adott kontextus sajátosságainak megfelelő mértékben fontos az anyanyelv szerepe a digitális identitásban. Például egy nemzetközileg is ismert youtuber csatornájának akár több milliós nemzetközi követői csoportjában a követők anyanyelve nem lényeges, hisz az interakciók (kommentek, diskurzusok, tetszésnyilvánítások, emotikonok használata) nem kötődnek az anyanyelvhez, hanem inkább a közösség által használt közös nyelven zajlanak, és ez jellemzően az angol. A digitális, online tér nemzetközi közösségi színterein a nagyobb követőtáborok tagjainak az identitásában az anyanyelv kevésbé van kitüntetett helyen, mint 
a hagyományos nemzeti identitás esetében. Ugyanakkor nyilvánvalóan van olyan digitális környezet is, amelyben az identitás meghatározó része az anyanyelv, például a szakmai blogokban, a tematikus, szakmai online médiafelületeken stb. Attól, hogy valaki az online tevékenysége során részben vagy akár döntően angolul kommunikál és nem az anyanyelvén, attól még nem veszti el nemzeti identitását, de vitathatatlan, hogy anyanyelve kevésbé lesz fontos a digitális identitásában, mint a nemzeti identitásában.

Megele, Buzzi és Longfield vizsgálódásának a középpontjában is a gyermekek állnak, ez ráirányítja a figyelmünket arra, hogy a digitális környezet és az identitás viszonyának vizsgálatakor a generációkat külön is érdemes megvizsgálni. Megeléék modellje szerint a gyermekek identitását a következő tényezők alakítják:

- játékok, online vagy videojátékok,

- internetfüggőség, túlzott internethasználat és online szerencsejáték,

- szexuális zaklatás, a szakkifejezés idegen alakja a sexting, pontos jelentése 'szexuálisan explicit fotók vagy üzenetek küldése mobiltelefonon, internetes üzenetben',

- online simogatás (a kifejezés idegen alakja: grooming) és az ezzel együtt járó szexuális zaklatás: az online simogatás jelentése így írható le: 'online udvarlás úgy, hogy másnak adja ki magát az udvarló, mint ami valójában, abból a célból, hogy a gyermek bizalmának megnyerése után őt szexuális visszaélés áldozatává tegye’,

- internetes zaklatás, online sértegetés,

- kiberbünözés,

- online radikalizálódás (Megele, Claudia, Buzzi és Longfield 2018).

Megeléék a modelljükbe azokat a tényezőket emelték be, amelyektől meg kell védeni a gyermekeket, mert éppen az identitásuk fejlődése miatt sérülékenyek. A fenti felsorolást kiegészítem azzal, hogy az identitásra a következő digitális tényezők is hatnak, ezek viszont lényegesen kevesebb veszélyforrást tartalmaznak a fentiekhez képest:

- multilingvális környezet,

- idegen nyelvek és kultúrák hozzáférhetősége,

- mindig hozzáférhető adatforrások, tudásbázisok,

- állandóan rendelkezésre álló kommunikációs csatorna,

- anonim kommunikáció lehetősége (kreativitás, normarelativizálás),

- könnyen elérhető és szerveződő közösségek,

- e-kultúra (e-learning, e-banking stb.).

A generációk identitását különböző mértékben határozza meg az online környezet. Az 1990-es évek közepétől lesz érzékelhető a mai értelemben vett online világ és a vele járó információtechnológiai környezet hatása.

A nagy generáció vagy baby boom generáció az elfogadott csoportosítás szerint 1946-1964 között született, és az 1990-es évek elején 25-45 éves felnőttek, akik akkor az aktív időszakuk közepén voltak. Ez a generáció a tanulmányait már jórészt befejezte az internetes világ kezdetekor, az aktív életét már 
elkezdte, illetve már karrierje középső szakaszában tartott. Ez a társadalmi csoport lassan alkalmazkodik a digitális világ új környezetéhez, nincs azonnali hatása a digitális környezetnek se a személyes, se a nyelvi identitására. Digitális és személyes identitása között erős kapcsolat figyelhető meg, és ez a nyelvhasználatra is igaz.

X generáció az 1965-1979 között születettek nemzedéke. Az 1990-es évtized elején 10-25 évesek. A legidősebb tagjaik is legfeljebb az aktív pályájuk, a fiatal felnőttkoruk kezdetén tartanak, már fiatal korukban megjelenik az online környezet és az információtechnológia, kénytelenek abba belenőni, alkalmazkodni hozzá. Ők alkotják az új technológiát követők, a tudatos alkalmazók táborát. Ezzel együtt gondot okoz nekik az új környezet, a nagy információmennyiség, a hagyományostól eltérő tanulási és információszerzési kontextus, mert az iskolában, a családban, a korai szocializációjuk során ezzel még nem találkoztak. Éppen ebből fakad, hogy tudatosabban viszonyulnak a digitális kultúrához, az információtechnológiához, kritikailag kezelik a hatásait. A digitális identitásukat tudatosabban alakítják, az internetet, annak felületeit, szolgáltatásait, közösségeit otthonosabban használják a nagy generációhoz képest, így digitális identitásuk is összetettebb, de tudatosan kezelik az internet nyilvánosságát, és ennek megfelelően építik digitális identitásukat is.

Az Y generáció besorolására több elmélet is van, az egyik szerint az 19801994, a másik szerint az 1980-2000 között születettek alkotják ezt a nemzedéket. Én az utóbbi felosztást követem. Ennek a generációnak természetes az online környezet, ebbe nőnek bele. Igaz, hogy a kisgyermekkori szocializációjuknak fontos része még az offline kultúra is, és kisgyermekkorukban még csak nyiladozik, kezdődik az online világ, az információtechnológia a maihoz képest fejletlenebb, kezdetben kevés a weboldal, az online tartalom, az internetet leginkább e-mailezésre, digitális párbeszédekre használták. A kezdeti időszakban nincs még web 2.0, nincs közösségi média, fejletlenek az online keresők. Már van mobiltelefon, de nincsenek még okostelefonok. Tari Annamária szerint viszont miután megjelenik a közösségi média, a web 2.0, az Y generáció természetes módon használja azt, és ennek következtében kollaboratív, nyitott szemléletű, csapatban dolgozik, fontos számára a csoportkonszenzus (Tari 2015, 50). Székely Levente a Magyar Ifjúság 2012 című kutatásban ismerteti, hogy ennek a korosztálynak a 42\%-a tanul, 39\%-a dolgozik, 16\%-a kivár: ők a bizonytalanok. További 4\%-uk dolgozik és tanul egyszerre (Székely 2012). Ebből is kitűnik, hogy az Y generációban érzékelhető a bizonytalanság, a kivárás, ez alacsony önértékeléssel járhat együtt: tapasztalható a „nem kellek senkinek” és a „nem tudom, hogy mit akarok” érzés. Ez a generáció a digitális környezet adottságait, jellemzőit ismeri, érti, a digitális identitás számukra kifejezetten fontos, tudatosan alakítandó tényező, amely nyomot hagy az identitása többi rétegén is.

A Z generáció a legfiatalabbak korosztálya, ők születtek 2000 után, szokás ezt a korosztályt a millenniumi nemzedéknek is nevezni. Többségük most középiskolás, legfeljebb kezdő egyetemista vagy fiatal munkavállaló. Már 
alapvetően meghatározza az identitásukat az online kultúra, kisgyermekkoruk óta fejlett, gazdag online és információtechnológiai környezet veszi őket körül. Számukra már kezdettől fogva vannak közösségi hálózatok, web 2.0, rengeteg online tartalommal találkoznak, egyre több a multimédiás tartalom, természetes számukra az okostelefonok, a mobil internet világa, és az ezzel együtt járó állandó elérhetőség és folyamatos online kommunikáció igénye. A digitális identitásuk nyílt, mindenki számára hozzáférhető; rájuk már erősen hatnak az online tér veszélyforrásai is, de az egyéb kommunikációs hatásai is. Tari Annamária szerint ez a generáció inkább a saját különleges képességeiben hisz, mint a kemény munka eredményében (Tari 2015, 52). Ennek a generációnak a nyelvi kompetenciája alakulóban van, jellemzően a nyelvi szocializáció második (iskolai) szakaszában tartanak, és ebben minden eddiginél lényegesebb szerepet játszik az online környezet. Ebben pedig alapvetően fontos a többnyelvűség, a globális angol dominanciája, a multimediális szövegalkotás, a gyors, gyakran leegyszerüsített nyelvhasználat. Ennek a nemzedéknek a digitális identitásában érhető tetten a leginkább a digitális identitásban a kimunkált anyanyelv szerepének a relativizálódása.

\section{Az anyanyelv szerepe a digitális identitásban}

Mivel a fentebb idézett kutatók szerint leginkább a digitális térben, azon belül is a közösségi médiában folyó diskurzusainkban érhető tetten az identitásunk online reprezentációja, ezért törvényszerűen fontos tényező az anyanyelv vagy az a nyelv, amelyen ezeket a diskurzusainkat folytatjuk.

A kibertér multilingvális, multikulturális, dominánsan angol nyelvü környezetében pedig a magyar nyelv használatának a háttérbe szorulása nem okoz törvényszerűen identitásvesztést, hanem csak azt jelenti, hogy a nemzeti identitás egyik lényeges szimbóluma, a magyar nyelv nemzeti identitásjelölő funkciója itt, bizonyos kommunikációs formákban gyengül, ám ez az összefüggés csak a kibertérre, és annak is csak bizonyos szövegtípusaira érvényes. Olyan ez az összefüggés, mint az írott beszélt nyelv magyarázata: az írásbeliség normalizáltságára, szabálykövetésére, szabályszerűbb voltára érvényes általános elvárás a kibertérben (bizonyos szövegtípusokban, kommunikációs formákban) relatívvá válik, de ez még nem feltétlenül okozza, hogy a kibertéren kívüli szituációkban is az írott beszélt nyelv lesz domináns (Bódi 2004, 56). Tehát attól még nem veszti el valaki a nemzeti identitását, hogy a kibertérben nem csak magyarul kommunikál, nem csak magyar nyelvü tartalmakat fogad be és oszt meg.

Az identitás több rétegü, a digitális identitás esetében az anyanyelv szerepe viszonylagos. Jól jelölheti viszont a földrajzi pozícióhoz kötött domainnév, a digitális filmfolyamokban (streamekben), filmterjesztésben használt régiókódolás. De természetesen az anyanyelvi vagy más nyelvi írásbeliség lényegesebb a digitális régiókódolásnál, domainnévstruktúránál. 
A közösségi hálózatok írásalapú virtuális társadalmat alakítottak ki, ahol rövidebb-hosszabb, lényegre törő üzenetekkel kommunikálunk, de kevesebb csatornát használunk, mint a valóságban, ezért homályosabb is a kép a partnerről (Tari 2015, 31). Előfordulhat, hogy a nyelvhasználatunk kevésbé kontrollált az online térben, mint az offline valóságban, ez is bizonyítja, hogy az online identitásnak az anyanyelvi müveltség, a nyelvhelyesség kevésbé fontos része, mint az offline térben. Az a csoportnorma érvényesül az online térben is, amelyik erős, ha az anyanyelvi csoportnorma nem erős, akkor nem érvényesül. Ezt lehet erősíteni pozitív mintákkal, a személyes motiváció erősítésével.

Ha valakinek nincs közösségimédia-profilja, esetleg csak passzív szemlélő, tehát nem tesz közzé tartalmakat, nem vesz részt diskurzusokban, nem nyilvánít véleményt, csak olvas, befogad, vagy minimális a digitális tevékenysége, attól még van identitása az illetőnek. Csak éppen a digitális környezet nem, vagy csak kevésbé járul hozzá, illetve a digitális környezetben csak minimálisan vagy hiányosan reprezentálódik.

A digitális, online tér fokozottabban és direktebb módon multilingvális, mint az offline tér, sokkal könnyebben, gyorsabban és tömegesebben érintkezünk többnyelvü tartalmakkal, mint az offline térben. A digitális környezet többnyelvű, az aktív digitális tevékenységgel rendelkezők identitásának többé vagy kevésbé részévé válhat a multilingvális tartalmak befogadása, esetleg alkotása, azaz a többnyelvűség.

Azokban az online kommunikációs formákban, amelyekben a reaktív és az interaktív hajlam kerül előtérbe, rövidül a figyelem időtartama, az elvont gondolkodással szemben a képekben való gondolkodás válik dominánssá. A tények, adatok zsúfoltsága figyelhető meg, de a kontextusba helyezés képessége, az értelmezés szintje gyengül (Greenfield 2009, 259). A XXI. században könynyen lehet rengeteg adathoz jutni, de a lényeg egyre inkább arra tevődik át, hogyan lehet igazán jó, célravezető, értelmes kérdéseket feltenni (Greenfield 2009, 263), mert a korlátlan mennyiségű adat értelmezésére nincs elég kapacitásunk. A megtalált adatok értelmezéséhez arra van szükség, hogy a meglévő fogalmi kerekekkel össze lehessen őket vetni, ehhez pedig idő kell. Az olvasás éppen ezt az értelmezésre rendelkezésre álló időt adta meg, de a pillanatnyi adatelérés és a képi kultúra, a képi gondolkodásmód korában nem jut elég idő az értelmezésre. Az információs társadalom meghatározó eleme az információ, amelyet az adat, a hozzá kapcsolódó tudás, illetve annak kommunikációja határoz meg (Pintér 2007, 20). A digitális identitásnak tehát része az adatszerüség, de már a tudás (értelmezés) és a kommunikáció (adathasználat) is fontos tényező.

A XXI. századi információs társadalom digitális infokommunikációs technikáinak gyorsasága és azonnalisága megteremti az igényt az érzelmi szükségletek és az információigény azonnali kielégítésére, az infotechnológia azonnali kommunikációs képessége miatt az emberi kapcsolatainkban (offline és online egyaránt) az azonnaliságot, az azonnali megoldásokat és válaszokat várjuk el, és ez rontja a hagyományos emberi kapcsolataink minőségét. Az online 
identitásnak tehát része az itt és most, azonnal megoldani mindent elvárása, ezért egyre több információ, adat, tudás jut el hozzánk, egyre többet kommunikálunk az új infokommunikációs eszközöknek köszönhetően, ezért pedig felborul az időmérleg, egyszerűbben fogalmazva: semmire sincs időnk (Tari 2015, 97). A digitális kultúra hatására az identitásunk nyomatékos elemévé válik a személyes időmenedzsment, illetve az időhiány érzésének a konfliktusa. A digitális infokommunikáció azonnalisága a konfliktusmegoldó-képességünket is befolyásolja: sokkal könnyebb és gyorsabb az infokommunikációs csatornákon megoldást keresni, segítséget kérni, mint önállóan megoldani a konfliktusokat. Ez azonban ellentmondásban áll azzal, hogy minden ember a problémáit először ösztönösen saját maga akarja megoldani. Viszont ha minden megoldást kívülről várunk, akkor ez hamar konfliktust okozhat.

Ezt kiegészítem azzal, hogy a valós, személyes érintkezés hiánya, a gyors és egyszerű kommunikáció gyakorlata, a képi és a szimbolikus tartalom térnyerése is szerepet játszik abban, hogy a virtuális térben a nyelv szerepe relativizálódik, pontosabban más az a nyelv és nyelvhasználat, amely a virtuális térben zajló kommunikációnk eszköze. A közösségi médiában zajló diskurzusok átveszik a terepet a valós térben zajló párbeszédek elől, és így a valós térben zajló, egyidejü, szemtől-szembe történő párbeszéd sok csatornája által hordozott információk nagy része és ezzel együtt az egymásra figyelés is elvész. A közösségi hálózatokon zajló diskurzusok lényegre törők, kevésbé felszínesek - állítja Tari Annamária. Az offline csevej sok csatornás egymásra figyelése hiányzik az online térből (Tari 2015, 26). Kiegészítem ezt azzal, hogy a kommunikáció átalakul az online térben, és más csatornákon szerezzük be az információkat a partner identitásáról, mint a fizikai térben zajló diskurzusok során.

Érdemes azt is megjegyezni, hogy a technika fejlődésével a viselhető eszközökön keresztül és az dolgok internetének - az Internet of Thingsnek, a hálózati kapcsolatban lévő használati tárgyainknak - köszönhetően a hangutasításoké a jövő: a szövegek, majd a multimédia világából átlépünk a hangok világába. Ez elhozhatja azt az időszakot, amikor az írott beszélt nyelv és a szimbolikus írásbeliség (Bódi 2004, 56; Bódi 2005, 195-212.) után az újjáéledt verbalitás korszakába lépünk.

\section{A digitális identitás további összetevői}

Az internetes hálózatok része a játék, és ez hatást gyakorolhat az identitásra is. Ez különösen a korábban jellemzett Z generációra, és azoknak is a fiatalabb tagjaira jellemző. Egy játékos identitására jellemző, hogy a digitális és videojátékok környezetében alternatív identitásokat, avatárokat építhet ki (vagy adott esetben szükségszerűen ki kell építenie) magának (ifj. Csákvári 2016). Tehát - legalább is a fiatalabb, játékos generációk esetében - a digitális identitás részének tartom az avatárokat, bár ezek valós kommunikációs szerepe minimális, és nem szükségszerű a jelenlétük. 
A digitális identitás olyan dimenziókra is érvényes terminus, mint az online biztonság, a digitális tartalmak feletti kontroll vagy a magánélet és a nyilvánosság kérdései (Fehér 2014, 140-142). A Foresight Future Identities 2013. évi kutatása a következő tíz évre azt jósolja, hogy az internet nem egy újfajta identitást termel, hanem abban játszik szerepet, hogy felismerjük: kulturálisan és kontextuálisan sokkal összetettebb jelenség az identitás, mint azt korábban gondoltuk. A jelentés előrejelzése szerint az Én adatkészlete növekszik, és különböző céloknak rendelődik alá a fogyasztói preferenciák megértésétől az adatbázisok építéséig és a felhasználói profilok feltöltéséig. A jelentés végül arra a következtetésre jut, hogy az offline és az online identitás megkülönböztetése a következő évtizedben már lényegtelenné válik, s a lét különböző aspektusai digitálisan jelennek meg (Fehér 2014, 142). Az előrejelzést igazolni látszanak napjaink történései a digitális térben, a 2010-es évek végén kezdtek rádöbbennek a felhasználói tömegek arra, hogy a digitális térben keletkező személyes adataikból milyen adatbázisokat, személyes profilokat lehet felépíteni, és hogy a digitális identitásukkal élnek és visszaélnek a közösségi hálózatok, az online marketing szereplői.

Itt válik fontossá az adatvédelem, a nyilvánosságra hozott vagy privát körben tartott adatok kérdésköre, az automatikus adatgyüjtés kontrollálása, lásd például a cookie-jóváhagyás kérdését, illetve a kérdéskör általános jogi szabályozására tett leglényegesebb európai kísérletet, az Európai Unió Általános adatvédelmi rendeletét, a GDPR-t.

A kibertérben megnövekedett a transzparencia: a privát szféránk nyilvánossága, az átláthatóság növekedésével a személyes tér csökken, és ez önértékelési problémát is okozhat, de egyszersmind adatvédelmi kérdéseket is felvet. Keleti Arthur kiberbiztonsági szakértő szerint hozzá kell szoknunk, hogy a kibertérben az aktivitásunkat elemzik. 2016-os könyvében a Gartner kutató és tanácsadó cég 2013-ban közzétett előrejelzését idézi, miszerint a rendelkezésünkre álló technológiák segítéségével 2020-ig az online elérhető adataink 75\%-át képtelenek leszünk megvédeni. Keleti szerint a négy legféltettebb titkunk közül három teljesen nyilvánosan elérhetővé válik ekkorra (Keleti 2016, 18). Ehhez hozzáteszem, hogy ráadásul még tudatában sem vagyunk annak, hogy ezek közül a személyes adatok, titkok közül melyek váltak nyilvánossá.

\section{Stratégia a digitális identitás kialakításához}

Összefoglalásképpen a digitális identitás, a nyelvi identitás és a digitális kommunikációs környezet összefüggéséről az alábbiakat állapítom meg. A digitális identitás az online tevékenységünk során kialakuló digitális adatokban megnyilvánuló online énreprezentáció, összehasonlító jellegű, az egyéni jellemzők kiemelése a meghatározó eleme, így itt a közösségi normák kevésbé fontosak, (így például az anyanyelv sztenderd változata sem minden helyzetben meghatározó a multilingvális online térben); digitális identitás lényeges eleme, hogy 
mi magunk, tudatosan formálhatjuk, szükségszerü kapcsolatban van a személyes identitásunkkal, de nem egyezik meg azzal. A digitális környezet a technológiai adottságaival a leegyszerúsített, szűkített kommunikációs csatornákon zajló kommunikációs folyamatokat és nyelvhasználatot részesíti előnyben, a multilingvális virtuális tér rontja az anyanyelvek versenyképességét a globális angolhoz képest, és így beépül a digitális identitásunkba, hogy csak az adott kontextus sajátosságainak megfelelő mértékben fontos az anyanyelv szerepe.

Ezek alapján egyértelmű, hogy lehet és kell digitálisidentitás-stratégiát kidolgozni. A virtuális teret müködtető szabály- és normarendszerek alapján építjük ki a virtuális személyiségünket, digitális identitásunkat. Ezeknek a szabályszerüségeknek az ismeretében lehet kialakítani a kibertérhez való tudatos viszonyrendszerünket.

A digitálisidentitás-stratégia legfontosabb szempontjai:

- a digitalizált adataink ellenőrzése, az adatvédelem, az adatkezelés kontrollálása,

- a virtuális közösségek és hálózatok kezelése (kapcsolatok, tartalomszerkesztés, kereshetőség),

- a láthatóság vagy a láthatóság hiánya,

- a rólunk alkotott véleményekre való reflektálás, és ez alapján a személyes előmenetelünk segítése,

- a karriercélok felállítása,

- a tudatosság vagy annak hiánya (Fehér 2014, 147).

- Mindezt kiegészítem a következő szempontokkal:

- a virtuális térben való kommunikációs formáink és a nyelvhasználatunk tudatos alakítása,

- az anyanyelvhasználathoz, illetve a nyelvválasztáshoz való viszony.

Az identitás egyre jobban vetül ki a digitális térre, és a digitális tér is egyre jobban befolyásolja azt. A digitális identitás összetétele, rétegei a digitális tér változatossága és változékonysága miatt, meg a közösségi hálózatok sajátosságai miatt is egyre jobban, egyre nagyobb tempóban változik. A digitális identitás csak részben alakítható és ellenőrizhető, ahogy ezt a digitális lábnyom esetében már elemeztem.

Nyelvstratégiai jelentősége van a honosításnak és az anyanyelvi tartalmak mind szélesebb körben való alkotásának, fogyasztásának. Mindez központi tényező abból a szempontból, hogy a digitális környezetben kiépülő identitás, illetve indentitáselemek között az anyanyelv jelentősebb szerepet játsszon.

Ha a társadalomban olyan változások vannak, amelyek az idegen kulturális elemek, az idegen nyelvi elemek, az idegen nyelv használatát - bizonyos szituációkban, akár a kibertérben is - megengedik, akár megkövetelik, akkor az módosítja az identitásfogalmat is: olyan nyelvi elemek, nyelvhasználat is részévé válik, amely korábban nem volt az. Ez legfeljebb a nyelvi versenyképességet csökkenti (Kiss 2018, 11). Ám mivel a magyar nyelv kitüntetett nemzeti identitásképző tényező, a nyelv versenyképességének a digitális térben való fenntartása nyelvpolitikai, sőt nemzetpolitikai tényező is. 
Az edutainmentnek (szórakozva tanulásnak) és a gamifikációnak (játékosításnak) köszönhetően a digitális kultúra is részévé válik a gyerekek identitásának. A digitális játékkörnyezetben kialakuló kultúra, a hálózati szerveződés és a technikai szakértelem is részévé válik a digitális identitásnak (Ito et al. 2010; ifj. Csákvári 2016). A szocializációs színtereken, a családi, az iskolai, a munkahelyi környezetben tudatosan kell alakítani és alkalmazni az identitásformálásra ezeket a digitális technológiákat és módszertanokat. A gyermekek nyelvi szocializációjában a digitális identitásuk nyelvi rétege erőteljesen befolyásolja a nyelvhez, az anyanyelvhez, az idegen nyelvekhez való viszonyukat. Ha a hálózati játékkörnyezet nyelvhasználata idegen nyelvi mintákat követ, és ha a digitális identitásuk természetes része a játékkörnyezet, akkor a nyelvi identitásukba is beépülnek ezek a minták. És az anyanyelv egy újabb területen válik - legalább is a fiatal, játékos generációnak - versenyképtelenné.

Az iskolában is elszigetelődik a gyerekek digitális identitása, amelynek a fő oka a generációs különbségeken túl az oktatástechnológia elmaradottsága (ifj. Csákvári 2016). Hozzáteszem, hogy Magyarország Digitális Oktatási Stratégiája, illetve a Digitális Pedagógiai Módszertani Központ tevékenysége során 2019-ben egyre több iskolában meginduló digitális oktatási programok, digitális témahetek javítanak ezen a helyzeten (https://dpmk.hu/). Ráadásul 2020 kényszerü, radikális, hirtelen változást hozott ezen a téren a Covid-19 világjárványa miatt életbe lépett digitális oktatás miatt. De a digitális oktatási színtereken nem a gyermekek egyes játékközösségekben és kisebb közösségekben kiépülő digitális identitása lép színre, hanem egy esetlegesen kialakuló iskolai digitális identitás, amelynek erős meghatározója az anyanyelv, az iskolai kultúra és szabályrendszer.

Rab Árpád és Z. Karvalics László az információs írástudás három szakaszát határolja el:

- 1970-es évektől: az írás, olvasás, számolás után a 4. alapképesség az információs környezetben való eligazodás képessége (számítógép-használat is),

- a digitális erőforrások hatékony kihasználása: keresés, hálózati navigáció, ügyintézés, kommunikáció, saját tartalmak megjelenítése,

- amikor a mindennapi társadalmi gyakorlat egyre több információs művelete kerül a virtuális térbe: vásárlás, álláskeresés, közéleti tevékenység, az egyéni és a társadalmi cselekvés közvetlen hatékonyságnövelését ígéri, ezek kiemelten fontosak itt: játék-írástudás, tudományos írástudás, egészségügyi írástudás, részvételi írástudás, pénzügyi írástudás, pszichológiai írástudás, jövő-írástudás (Rab Árpád és Z. Karvalics 2017, 72-73). A digitális írástudás ebben az értelemben történő fejlesztése, alkalmazása szintén hozzájárul a digitális identitás formálódásához.

A digitális kontextus által befolyásolt nyelvhasználat is sokféle: van internetes, online nyelvhasználati mód, amely jellegzetes eltéréseket mutat az offline, hálózaton kívüli nyelvhasználattól. Stratégiai jelentősége van a digitális identitásunk alakulásában, alakításában annak, hogy a kibertérben zajló dis- 
kurzusainkban tanúsított magatartásunkat, nyelvhasználatunkat tudatosan kontrolláljuk, alakítsuk és a digitális kontextusban használjuk.

Greenfield szerint a képernyőről olvasás semmivel sem rosszabb, mint a könyvből olvasás, a nagy eltérést a multimédia szöveg feletti térnyerése okozza (Greenfield 2009, 166). A kibertér multimediális világa, a videojátékok ingergazdag vizuális környezete a gyakori felhasználók (gyerekek) esetében referenciaként szolgál, és a valós világ lényegesen lassabban változó, lényegesen ingerszegényebb vizuális környezetében sokkal könnyebben elsiklik a figyelmük, terelhetővé válnak a gondolataik, sokkal kevésbé képesek az ingerszegényebb valós környezetben kitartóan koncentrálni egy feladatra. A vizuálisan és multimediálisan ingergazdag kibervilág a retorikai érvelési, gondolkodási képességek elé akadályt állít, és csökkenti a képzelőerőt is.

A képernyőn felnőtt (1990-es években született) generáció a nyelvi metaforákat kevésbé érti, mert a képernyőn megjelenő képeken növekedett fel (Greenfield 2009, 174). Mindez erősíti azt a megfigyelést, hogy a nyelv a kibertérben egészen eltérő normatívák szerint működik, mint az internet előtti hagyományos, offline világban. A szoftverek kezelőfelületének alapvető jellemzője, hogy a menüstruktúrájukban, a könyvtárszerkezetükben véges számú lehetőség közül választva lehet tájékozódni felfelé és lefelé mozgással. Ez egyrészt fegyelmezettebbé teszi a lineáris gondolkodásmódot, másrészt pedig gyengíti a föl-le lépcsők megkerülését lehetővé tevő gondolkodásmódot, jelentésértelmezést.

Az okoseszközöket használjuk, kedveljük: „De nem kellene odáig eljutni, hogy nélkülük már nem tudjuk, kik is vagyunk és hol a helyünk a saját életünkben.” (Tari 2015, 103) Az ultramobil okoseszközök, amelyek állandóan azonosítanak minket, tulajdonosokat, és állandóan megjelenítenek mindet az online térben, gyakran azonosítóeszközként is szolgálnak: felhasználónevek, becenevek, avatárok, a felhasználói fiókok és az azokban megadott személyes adatok, a fizikai helyzetünk, online tevékenységünk, érdeklődésünk kielégítője, tájékozódásunk segítője. Az okoseszközök a cselekvéseink, tulajdonságaink, kommunikációnk, kapcsolataink múltjának rögzítői, jelenben való lehetőségeink biztosítói. Az okoseszközök valójában identifikáló eszközök, olyanok, mint a személyi igazolvány, csak sokkal több adatot rögzítenek, így sokkal alaposabb képet adnak az identitásunkról, identitástípusainkról. Ezek segítségével egyre nagyobb szerepet tölt be a digitális identitás a személyes identitásunkban.

A kibertér általános közvetítőnyelve az angol. Ez a magyar nyelv versenyképességének csökkenését okozza ezen a nyelvhasználati színtéren, ha nincs honosítás, ha nincsenek magyar nyelvű tartalmak. Minél jobban fejlesztik a magyar nyelvű információtechnológiát és terminológiát, minél több és minél jobb minőségű (kidolgozott, hibamentes stb.) magyar nyelvi anyag van a világhálón, illetve digitalizált formában, annál jobban nő anyanyelvünk versenyképessége ezen a színtéren.

$\mathrm{Az}$ alapidentitás a nemzeti identitás, ebből vezethető le (nem vagylagosan, hanem kapcsolatos logika alapján) a helyi, lokális identitás, ami jellemzően az 
anyanyelvben nyilvánul meg (Péntek 2010, 165). A kibertérben nincs földrajzi értelemben vett lokalitás, mindezt a nyelvi-kulturális honosítással teremtjük meg.

A világháló nyelvi környezete többnyelvü, multiligvális. És ezen a színtéren a nyelvek olyan mértékben, olyan arányban vannak jelen, amekkora arányt megkövetel a beszélőközösség. Fontos nyelvstratégiai cél tehát a nyelvmegőrzés szempontjából az anyanyelvi tartalmak publikálása, gyarapítása a világhálón.

A kibertér tehát többnyelvü, és mindaddig felcserélő és nem hozzáadó típusú az ott fennálló többnyelvűség, amíg kényszerűségből kell egy másik nyelvet vagy annak terminológiáját, szaknyelvét használni, mert nincs honosítás vagy nincs elérhető, megfelelő mennyiségű vagy minőségű anyanyelvi tartalom. Ezért kellenek tudatos nyelvstratégiai lépések az anyanyelvi tartalom digitalizálására, a honosítás koordinálására és a nyelvi tanácsadásra.

\section{Irodalom}

Bódi Zoltán. A világháló nyelve. Internetezők és internetes nyelvhasználat a magyar társadalomban. Budapest: Gondolat Kiadó, 2004.

Bódi Zoltán. „Szimbolikus írásbeliség az internetes interakcióban”. In Balázs Géza, Bódi Zoltán (szerk.), Az internetkorszak kommunikációja. Tanulmányok, 195-212. Budapest: Gondolat Kiadó, 2005.

Csákvári József, ifj. „Számítógépes játékhasználat a szociális kompetenciák tükrében”. Új Pedagógiai Szemle, 66. évf 3-4. szám (2016):, 53-68. letöltés időpontja: 2019. október 10. https://folyoiratok.oh.gov.hu/uj-pedagogiai-szemle/szamitogepes-jatekhasznalat-aszocialis-kompetenciak-tukreben.

Deloitte. Tech Trends 2013. Elements of postdigital. letöltés időpontja: 2019. október 10. https://www2.deloitte.com/content/dam/Deloitte/us/Documents/technology/us-cons-techtrends-2013.pdf.

Digitális Jólét Program. DOS - Magyarország Digitális Oktatási Stratégiája. Digitális Jólét Program. A letöltés időpontja: 2019. október 10. https://digitalisjoletprogram.hu/hu/ tartalom/djp20-strategiai-tanulmany.

Fehér Katalin. „Milyen stratégiák mentén épül fel a digitális identitás?” Médiakutató 19. évf., (2014 nyár): 139-154.

Greenfield, Susan. Identitás a XXI. században. Budapest: HVG Kiadó, 2009.

Holt, Jennifer, Steven Malčić. „The Privacy Ecosystem: Regulating Digital Identity in the United States and European Union”. Journal of Information Policy Vol. 5, (2015): 155-178. Penn State University Press. https://doi.org/10.5325/jinfopoli.5.2015.0155. 
Ito, Mizuko, Sonja Baumer, Matteo Bittanti, danah boyd, Rachel Cody, Becky Herr-Stephenson, Heather A. Horst, Patricia G. Lange, Dilan Mahendran, Katynka Z. Martínez, C. J. Pascoe, Dan Perkel, Laura Robinson, Christo Sims, Lisa Tripp. Hanging out, messing around, and geeking out. Kids living and learning with new media. Cambridge, London: MIT Press, 2010. Keleti, Arthur. The Imperfect Secret. CreateSpace Independent Publishing Platform, 2016.

Kim, Hee Woong, Jun Raymond Zheng, Sumeet Gupta. „Examining knowledge contribution from the perspective of an online identity in blogging communities.” Computers in Human Behavior, Vol. 27, no. 5 (2011): 1760-1770.

Kiss Jenő. „Identitás és anyanyelv a magyarság történetében”. Magyar Tudomány 180. évf., (2017 július): 805-809. A letöltés időpontja: 2019. október 10. http://epa.oszk. hu/00600/00691/00166/pdf/EPA00691 mtud 201707 805-809.pdf.

Kiss Jenő. „A nyelvi versenyképesség és a szaknyelvek”. In Bódi Zoltán, Katona József Álmos (szerk.), Gazdaság és szaknyelv. Tanulmányok. 9-16. Budapest: Magyar Nyelvstratégiai Intézet, L'Harmattan, 2018.

Maslow, Abraham. A lét pszichológiája felé. Ursus Libris, 2016 [1968].

Megele, Claudia, Peter Buzzi, Anne Longfield, A. „Online identity, digital citizenship and boundaries”. In Megele, Claudia, Peter Buzzi (eds.), Safeguarding children and young people online: A guide for practitioners. 25-46. Bristol, UK; Chicago, IL, USA: Bristol University Press, 2018.

Péntek János. „Anyanyelv és identitástudat”. Debreceni Szemle 10. évf. 3. szám (2010): 160168. A letöltés időpontja: 2019. október 10. http://szemle.unideb.hu/wordpress/wp-content/ uploads/bsk-pdf-manager/70_2014-06-06.PDF.

Pintér Róbert. „Úton az információs társadalom megismerése felé”. In Pintér Róbert (szerk.), Az információs társadalom. Az elmélettól a politikai gyakorlatig, 11-28. Budapest: Gondolat - Új Mandátum, 2007.

Rab Árpád, Z. Karvalics László. „Harmadik generációs információs írástudás-fejlesztés a gyermeki életesélyek javításáért”. Információs Társadalom XVII. évf. 2. szám (2017): 69-77. http://dx.doi.org/10.22503/inftars.XVII.2017.2.5.

Sarma, Amardeo C., João Girão. „Identities in the Future Internet of Things”. Wireless Personal Communications, Vol. 49. no. 3 (2009): 353-363.

Schawbel, Dan. Én 2.0. Budapest: HVG Kiadó, 2009.

Székely Levente (szerk.). 10 kérdés az ifjúságról. Magyar ifjúság 2012. kutatás első eredményei. Kutatópont, 2012. A letöltés időpontja: 2019. október 10. https://kutatopont.hu/files/2012/02/ magyar_ifjusag_2012.pdf.

Tari Annamária. \#yz Generációk online. Tercium Könyvkiadó, 2015.

The Government Office for Science. Foresight Future Identities 2013, Final Project Report.

The Government Office for Science, London. A letöltés időpontja: 2019. október 10. https://assets.publishing.service.gov.uk/government/uploads/system/uploads/attachment data/file/273966/13-523-future-identities-changing-identities-report.pdf.

Vie, Stephanie (ed.). (E)dentity. Southlake: Fountainhead Press, 2011. 